\title{
Sleeping Out of Home in a Kibbutz Communal Arrangement: It Makes a Difference for Infant-Mother Attachment
}

\author{
Abraham Sagi \\ University of Haifa, Israel
}

\section{Marinus $H$. van IJzendoorn}

Leiden Unwersity, The Netherlands

\section{Ora Aviezer}

Institute of Research on Kibbutz Education, Oranim, and School of Education of the

Kibbutz Movement, Unwersity of Haffa, lsrael

\author{
Frank Donnell \\ Instutute of Research on Kibbutz Educution, \\ Oranim, Israel
}

Ofra Mayseless

University of Hatfa, Israel

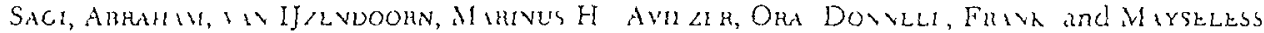
Orth Slecping Out of Home in a Kubutz Communal Arrangement It Wahes a Difference for

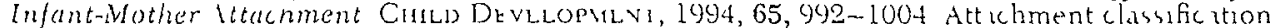
distributions of intunt-mother dyads living in 2 tvpes of Isiaeli hibbutzim were compatited The subjects were 48 inlunts, $14-22$ months old $(M=1829$ months) 13 bovs and 10 grrls were from 23 kibbutr infunts houses with communal sleeping arrangements and 13 bovs ind 12 guls were trom 25 hibbutz intants houses with home-b wed sleeping arrangements The 2 groups did not differ on intants' temperament and ealy life events, mother-intant plav interaction, quality of intants' davtime environment, or any of several maternal varubles Among the home-based infants, $80 \%$ were securely attached to then mothers versus $48 \%$ of the intants in communal sleeping ariangements No avoudant relationships were found Including the disorganized disoriented attachment classification (44\% in the communal group, 32\% in the home-based group) did not change the results We argue that the communal sleeping arrangement presents a childreaung environment that deviates markedly fiom the environment of evolutionary adaptedness
\end{abstract}

Bowlby (1984, p 60) emphasized the impoitance of observing the development of children rased within settings that deviate considerably from the so-called environment of evolutionary adaptedness. In our first study on the development of attachment in infants raised in Israeli kibbutzim (Sagi et al, 1985), we examined the security of infant-mother attachment when infants were being raised in a traditional kibbutz communal sleeping arrangement. Infants in this setting are exposed to child-rearing practices that differ markedly from those that attachment theorists consider desirable, and con-

This work was supported in part by funds provided to Abraham Sagi by the University of Hatfa Research Authouty and in part by a PIONEER grant awarded to Marmus $H$ van IJzendoorn by the Netherlands Organization for Scientific Research Frank Donnell's master's thesis at the University of Hafa was based on this study We are most grateful to Arza Avrahamı, the director of the Institute of Research on Kibbutz Education, fou her outstanding assistance and cooperation throughout the various phases of the study Special thanks are due to Zv1 Lavi and Michael Nathin, tormer dnectors of the Institute We should also like to thank Tirtsa Joels, Moshe Tuva, and Yael Harel for their unusual devotion in collecting and coding the data Finally, our deep appreciation to the ensly education coordinators, metaplot, and himilies in the vamous kibbutsun for then wim cooperition Conespondence concerning this uticle shoukd be addressed to tbrahum Sag1, Depatment of Psvchology, University of Hasta, Haita 31905, Isriel

[Chld Development, 1994 65, 992-1004 01994 by the Soc1ety for Reserrch in Chi'd Development, Inc All rughts resened 0000 3420/94/65010004501001 


\section{Child Development}

posed to communal These two conditions were naturally occurring kibbutz childrearing practices that could not be randomly assigned Accordingly, a quasi-experimental design (Cook \& Campbell, 1979) was adopted with the aim of demonstrating the similarity of the groups across crucial background information and potentially contaminating variables

Mothers' biographical charactenstics, including age, number of childien, education, professional tianing, and kibbutz experiences as a child, were considered background data The data conceining potentrally intervening variables consisted of apprasals of mothers' current job satisfaction, anxiety about separation from their intants, and attitudes toward their infants' houses, as well as observations of motherinfant interaction during a play session Infants' background information and possible intervening variables included infants' age, sex, percerved temperament, and critical early life events such as 1 llness and separation from parents tnother crucial comparison concerned the quality of care observed in each infants' house so we could examine the essential similarities in the daytime ecology of both groups of infants

Subjects

The subjects were 48 full-term, developmentally healthy infants aged 14 to 22 months $(M=1829, S D=225)$ from intact families Thurteen boys and $10 \mathrm{girls}$ were drawn randomly from 23 different kibbutz infants' houses with communal sleeping arrangements, and 13 boys and 12 girls were drawn randomly from 25 kibbutz infants' houses with home-based sleeping arrangements An infants' house normally consists of six infants and two caregivers The number of existing infants' houses in a given $\mathrm{kib}$ butz depends on the annual birth rate, which changes from year to year and from one $\mathrm{kib}$. butz to another (average is about 8-15 infants per year) We approached $50 \mathrm{kibbutz}$ infants' houses through the official channels of the Institute of Research on Kibbutz Education, which monitors all research activities conducted with kibbutz children One famlly had to leave the country unexpectedly after we obtained consent but before we visited, and one familv withdrew its consent Because this study is part of a larger project, we were unable to replace these two famihes For communal versus home-based infants, mean ages were $1874(S D=203)$ and 1788 (SD $=240$ ), respectively There was no significant assocration between the type of sleeping arrangement and the sex of the infants

We were well aware that many kıbbutzım were in the midst of an internal negotiation process regarding the sleeping arrangements for their children Therefore, only kibbutzim in which the communal sleeping arrangement had been conservatively observed were contacted In these kibbutzim, all of the infants and children slept in the infants' and children's houses prior to and at the time of our observations, and the membership assembly had not voted vet for a change in the communal sleeping arrangement The kibbutzim sampled in this study voted to change the communal sleeping arrangement anywhere between 8 months and 2 years after our observations ended, for manv, the delay was primarly caused by lack of sufficient resources to expand the size of each famly's living space In fact, sociohistorical observation of the emergence and adoption of "familism" ( $T_{1}$ ger \& Shepher, 1975) suggests that the transition of any specific kibbutz from a communal to a home-based sleeping arrangement does not stem from its members being more "child-oriented" than members of kibbutzim adhering to a communal sleeping arrangement In this respect, self-selection is not inherent in the sociohistorical development of the two groups

\section{Measures}

Mother Characteristics Questionnare-This questionnare consisted of items asking each mother about her age, education, profession, present occupation, and background in child care, as well as how she joined the kibbutz and the age and number of her children in addition, each mother was asked whether she chose or was assigned her present occupation This question was followed by three 10-point Likerttype items that gauged work satisfaction The first item, which referred only to mothers who had been assigned to their present job, asked how each felt when they commenced working In the second item, all mothers were queried about their current feelings at work For both questions, a score of 1 indicated disappointment and a score of 10 indicated that she felt very satisfied The last question tapped the extent to which each mother would like to act on her current teelings about hes job A score of 1 meant that she would preter to quit her present position, and a score of 10 meant she would rather stay 
Life Events Questionnatre - This questionnaire amed at tapping events in each infant's life that revolved around possible trauma and separation from parents The events investigated were chronic and acute llnesses, hospitalization, and separation from mothe1 and father Items included questions regarding the frequency of each event, its length in time, and the infant's age at time of occurrence Two separate scores were calculated for each of these event domans frecuency of occurrence, which is the number of times an event took place since the time of the infant's birth, and duration of occurrence, which is the total number of days Thus, for evample, a child being hospltalized once for 2 days and once tor 6 davs scores 2 on frequency of occurrence and 8 on duration

Infant Characteristics Questionnare (ICQ) - The ICQ (Bates, Freeland, \& Lounsbury, 1979) is composed of 32 seven-point items translated into Hebrew utilizing the guidelines set down by Buslin's (1980) backtranslation procedure Bates et al (1979) described the scale as consisting of factors for fussiness-difficultness, unadaptability, persistence, and unsociability in the piesent study, alpha reliabilities for these factors were $79,48,57$, and 22 , respectively Thus, only the fussiness-difficultness subscale was used in subsequent analyses A lower score represents an easier temperament and a higher score a more difficult temperament

Maternal Separation Anxiety Scale (MSAS) - Hock and associates (Hock, 1984, Hock \& Clinger, 1981, Hock, DeMeis, \& McBride, 1988) defined the variable of "maternal separation anxiety" for short-term separations as "an unpleasant emotional state reflecting a mother's apprehension about leaving her chıld" (Hock, 1984, p 194) The MSAS consists of 35 five-point, selt-report, Likert-scale items comprising three subscales maternal separation anxiety, peiception of separation effects of the child, and employment-related separation concerns (Hock, McBride, \& Gnezda, 1989) The items of the MSAS were translated into Hebrew, once again emploving the guidelines set down by Brislin's (1980) back-translation procedure

The Maternal Separation Anxiety Subscale (MSA) consists of 21 items that reflect the mother's expressions of anvety and feelings of guilt when separated from her infant, the Perception of Sepalation Effects on the
Child Subscale is composed of seven items relating to the mother's attitudes and feelings about her infant's reaction to separation, and the Employment-Related Separation Concerns Subscale contans seven items that assess the mother's attitude about balancing her maternal role and work Alpha reliabilities for the three subscales were 78 , 55 , and 25, respectively Thus, onlv the USA scale, which is the most basic and reliable one (Hock et il, 1989), was used in further analyses

Nursing Chuld Assessment Teaching Scales (NCATS) - The NCATS (Barnard et al. 1989) consists of observations duing a "teaching" session, the goal of which is to observe the interaction patterns that occur between the mother and her child The mother was asked to teach her child a playful task that the child developmentally could not succeed at quite readily These tasks were chosen from the Bayley Scales of Infant Development (Bayley 1969), and they were designed to be too difficult for the child to handle unless some assistance was provided by the mother Observations lasted for about $10 \mathrm{~min}$, prior to the administration of the Strange Situation All observations were videotaped

Rateis scored these observations using six scales For parents, the important behavlors wele sensituity to infant's cues (11 items), ability to alleviate the infant's distress ( 11 items), and ability to mediate the environment for the child in ways that foster cognitive development (17 items) and soctalemotional development (11 items) For infants, the primary behaviors were the ability to produce clear cues for the mother (10 items) and the ability to respond to the mother (13 ttems) Using the standard definitions for the VCATS, the observers were asked to decide whether each of the 73 items did or did not take place at least once (score of 1 for yes, score of 0 for no) Because very few infants showed distress, the scale for ability to alleviate the infant's distress did not have enough variance to be included in statistical analyses Scores for each of the five remaining scales were summed to establish total scores Interrater reliabilities were obtained bv Pearson correlations computed for the scores of the five scales, generated by two independent raters on 15 cases (mean $r=93$ )

Apprinsal of Infants' Houses Scale - A 13-item, self-report, five-point, Likert-type attitude scale, developed especially for this 


\section{Child Development}

study, asked the mother to reflect upon her appiaisal of the infants' house where her infant lived The mother was asked to indicate the extent to which the infants' house fulfilled her infant's needs and to indicate her attitudes toward the metapelet, her infant's peer group, and the infants' house itself $A$ high score indicated a positive attitude The alpha reliability of this scale was 75

Infant-Toddler Center Spot Obseruation System (ITCSOS) - Belsky and Walher (1980) developed this observation svitem to assess quality of calegiver interaction with intants in day-cale centers In previous studres, the measure shoved high short term stability (Lamb et al, 1988)

Caregiver behavior was rated over a 3 min period, utilizing a chechlist of events consisting of 13 positive and 7 negative items This is a binary coding system, where observers noted anv events occurring at least once within each 3-min episode Thus, the score for positive items ranged between 0 and 13 , and the score for negative items between 0 and 7

Positive events comprised caregiver behavior with reference to positive regad, empathy, verbal elaboration, heightened emotional display, transtorming routine into a learning expelience, concurient routine maintenance and infant engagement, nonstructured attention focusing, tacilitating peer interaction, dual child engagement, on floor involvement, and distant involvement, as well as the infant's behavioral display of happiness, and, finally, whether some of the activities of the infants' house featured nontoy play or exploration Negative items were child crying, child uninvolved or behaving aimlessly, caregiver prohibitions, child restrictive device, children waiting, routine as routine, and caregiver nonchild conversation

Six 3-min periods were observed during each visit These periods included parts of the "love hour" (Aviezer et al, 1989), mealtime, playtime, and caregiving/putting to bed Out of a total of 5,760 observations, 800 were observed independently br a second observer Interobserver reliability was $95 \%$ The ITCSOS was scored by summing across all of the six positive scores for each infants house observed and across all of the stx negative scores for each infants' house observed, thus generating two tot al composite scores

Strange Situation procedure -Infant- mother attachment is usually observed in the well-known Strange Situation procedure (Ainsworth et al, 1978), in which infantmother interaction during a series of increasingly stresstul episodes indicates the quality of their attachment relationship Infant's behavior during reunion with the mother after two 3-min separations is classified into three man categories of attachment Infants classified as securely attached (B) show minimal resistant and avoidant behavior, that is, a se curely attached intant is somewhat upset when the mother leaves but her return has a calming eftect intants classified as avordant $(A)$ do not seeh proumitv ol contact with the mother when she ieturns, but instead show avordant behavior Intants classified as iesistant or ambivalent (C) seek contact but at the same time resist the mother when she returns, some resistant infants are unable to settle within the 3 -min reunion episode

In the past, each intant-mother dyad has typically been "forced" into a best-fitting $A$, $B$, or $C$ attachment classification when the infant did not completely fit within the criteria set by the original classification system (Answorth et al, 1978) Recently, Vain and Solomon (1990) have suggested a fouth classification-disorganized/disoriented-tor such infarits Disorganized (D) infants show a momentary absence of any particular strategy for dealing with the separation stress and with the return of the mother, they show inconsistent behavior patterns, such as avordant as well as resistant behavior or the odd behaviors detaled by Main and Solomon (1990) Because the D category has not been validated as thoroughly as the original classifications, both $A B C$ and $A B C D$ outcomes are presented

The Strange Situation procedure was conducted on site in a manner similar to that reported in Sagi et al (1985) Strange Situation tapes were rated independently by three of the authors (Mayseless, Sagl, \& van IJzendoorn), who were blind to the infant's sleeping arrangement status $W_{1}$ th regards to the ABC system, mean interjudge reliability was $82 \%$ (mean kappa $=63$ ) Bearing in mind that the $A B C D$ system is lather new and not yet widelv used, it should be noted that van IJzendoorn reached $83 \%$ (kappa $=$ $76, N=30$ ) rehability agreement in a training session with Vary Vain and Sagi reached $86 \%$ (happa $=72, N=22$ ) reluabilitv agreement tor another hibbutz subsample after a training session with van IJzendoorn In the present studr, the ABCD system was 
applied through consensus between Sagi and van IJzendoorn

\section{Results}

Analyses of Similarities between the $\Gamma$ wo Sleeping Arrangements

We compased critical bachground factors and potentrally contaminating varables acloss the two groups-mothers and intants with communal sleeping ariangements versus mothers and infants with home-based sleeping arıangements

To compare the continuous measures for the communal versus home-based infants, a selles of VANOVAs and ANOVAs were computed The results obtaned fiom the multivariate and univariate analyses are summanzed in Table 1 These analyses ievealed significant effects only for the mean frequency and duration of mother-infant separations, the mean scores were gieate: for home-based infants Chi-square analyses of the categorical background variables of in fant health, mothers origin, and job satisfaction were also iun ts Table 2 shows, none of these were found to be significant

In all, the background characteristics of the communal and the home-based groups were very similai, which accords with ou hypothesis that the groups wele fiom essentially the same population of infants and motheis, with equiralent levels of darly care in the infants' houses thus substantiating the quasi-experimental design approach Furthermore, the observations of these motheis with their infants in a play session did not show any difference between the two groups

Only in one aspect did the two groups differ, in that mothers of home-based intants were more likely to leave their infants and for a greatel duration than were mothers of infants with communal sleeping ariangements To address the issue that Strange Situation classifications may be associated with frequency and duration of separation exper ences-an issue hotly debated in the daycare literature (e g, Belsky \& Biaungart, 1991) - we conducted Kruskal-Wallis oneway ANOVAs with separation measures as dependent variables and the $A B C$ classifica tions as the independent variable $A$ nonparametric approach was necessary because of the skewness of the separation measures Mean rank of separation duration for the insecure group was 2097 , and 2644 tor the secure group, $x^{2}(v=48)=181, p=18$ Mean lank of the separation fiequency was
2229 for the insecure group and 2571 for the secure group, $x^{2}(N=48)=75, p=$ 39) No significant iclations were tound for the analyses withn each gioup either

\section{Strange Situation Classifications}

The man attichment classification findings are presented in Table 3 , utilizing both the traditional $\triangle B C$ cirtera (set out by Answorth et al 19-8) and the recently developed ABCD classification system (Vain \& Solomon, 1990) Vo sex diffelences were tound Also, no arordant classifications were made for insecure infants in either group. and the majontr of the intants in the communal group were tound to be inseculeresistantly attached to therr mothers Compared to ealie studies using the ABCD system in noumal populations (Mam \& Solomon, 1990, van IJzendoorn, Goldbeig, Kioonenbeig, \& Fienkel, 1992), a substantial number of intants in each of the sleeping arlangement gioups weie classified as disorganized/disoriented Fuithermore, in both the $A B C$ and $A B C D$ classification systems, a significant association exists between the attachment classification and the sleeping arangement of the infant intants rased in the communal arrangement were found to be more insccure-ambivalently attached to their mothess than infants rased in the home-based an angement The adjusted standardized residuals for the $A B C D$ analysis showed that inclusion of the disorganized/clisonented category did not change this result

Because the only difference between mothers of home based infants and motheis of communal infants was that the former were more likels to leave their infants and for a gieater duration, we tested whether separation experience might have contaminated the relation between attachment and sleeping arrangement Separation experience was dichotomized (no separation, $n=$ 20 , one or more separations, $n=28$ ) to allow for log-Imea analvses The dichotomized separation varable still showed significantly more sepuation experiences in the homebased gloup, $x^{2}(\mathrm{~V}=48=181, \mathrm{df}=1)=$ $401, p=04$ In the saturated model, the three-way inteiaction sleep $\times$ classification $x$ separation was not significant (estumate for paramete: $=-15, z=-96, \mathrm{NS}$ ), ind cating that the relation between sleeping arrangement and attachment classification was not dependent on sepaiation experience The best fitting hierarchical (backward selection procedure) model contaned twowas interactions sleep $\times$ classification and 
TABLE 1

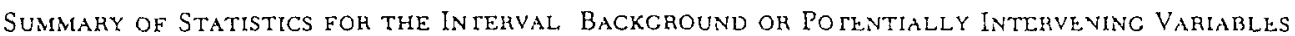

\begin{tabular}{|c|c|c|c|c|c|c|}
\hline & \multicolumn{2}{|c|}{$\begin{array}{l}\text { CommuvuL } \\
(\mathrm{V}=23)\end{array}$} & \multicolumn{2}{|c|}{$\begin{array}{l}\text { HOVE-BASED } \\
(\mathrm{V}=25)\end{array}$} & \multirow[b]{2}{*}{$F$} & \multirow[b]{2}{*}{$d f$} \\
\hline & $M$ & SD & $M$ & SD & & \\
\hline \multicolumn{7}{|l|}{ Mother variables } \\
\hline Number of children in the family & 239 & 233 & 208 & 135 & $<100$ & 1,46 \\
\hline Age (vears) & $327+$ & 472 & $30 \pm 0$ & 418 & 331 & 1,46 \\
\hline Education (vears) & 1396 & 113 & $13 \pm 0$ & 155 & 166 & 1,16 \\
\hline Job satisfaction & & & & & $<100$ & 39 \\
\hline How felt if job assigned & +36 & 212 & $51 \overrightarrow{1}$ & 240 & $<100$ & 1,11 \\
\hline Present job satisfaction & 736 & 230 & 784 & 234 & $<100$ & 1,45 \\
\hline Desure to change job & 605 & 351 & 680 & 361 & $<100$ & 145 \\
\hline Mateinal Separation Anrety Subscale & 1897 & 270 & $19+7$ & 322 & $<100$ & 1,46 \\
\hline Apprasal of infants house & 4526 & 576 & 4800 & 626 & $<100$ & 1,46 \\
\hline NCATS $^{3}$ & & & & & 106 & 343 \\
\hline Sensitivity to cues & 952 & 104 & 979 & 66 & $\overline{114}$ & $\overline{1,45}$ \\
\hline Socioemotional fostering & 961 & 84 & 954 & 93 & $<100$ & 1,45 \\
\hline Cognitive fostering & 1591 & 95 & 1554 & 172 & $<100$ & 1,45 \\
\hline \multicolumn{7}{|l|}{ Infant variables } \\
\hline Age (months) & 1874 & 202 & 1788 & 240 & 178 & 1,46 \\
\hline ICQ-fussy & 134 & 30 & 135 & 29 & $<100$ & 1,46 \\
\hline Hospitalization & & & & & $\leq 100$ & 245 \\
\hline Mean frequency & 57 & 84 & 36 & 64 & $<100$ & 1,46 \\
\hline Mean duration (davs) & 257 & 493 & 144 & 267 & $<100$ & 1,46 \\
\hline Acute llness & & & & & $\leq 100$ & 245 \\
\hline Mean frequency & 191 & 162 & $1 S 4$ & 155 & $<100$ & $\overline{1,16}$ \\
\hline Vean duration (davs) & 1257 & 1309 & 1112 & 1166 & $<100$ & 1,46 \\
\hline Separation from mother * & & & & & 326 & 2,45 \\
\hline Wean frequency & 52 & 67 & 129 & 134 & 600 & 1,46 \\
\hline Mean duration (days) & 174 & 329 & $4+8$ & 538 & 444 & 1,46 \\
\hline Separation from father & & & & & 125 & 2,45 \\
\hline Mean frequency & 191 & 173 & 240 & 141 & 115 & $\overline{1,46}$ \\
\hline Mean duration (davs) ${ }^{h}$ & 3839 & 4652 & $39+0$ & 3186 & $<100$ & 1,46 \\
\hline NCATS & & & & & 1.25 & $\underline{2,45}$ \\
\hline Clarity of cues & 896 & 88 & 875 & 126 & $<\overline{100}$ & $\overline{1,45}$ \\
\hline Responsıveness to mother & 861 & 156 & 883 & 171 & $<100$ & 1,45 \\
\hline \multicolumn{7}{|l|}{ Quality of group care } \\
\hline ITCOS & & & & & $\leq 100$ & 2,45 \\
\hline Positive & 2539 & 751 & 2740 & 549 & $\overline{\mathrm{NA}}$ & \\
\hline Negative & 1109 & 264 & 1116 & 310 & $\mathrm{NA}$ & \\
\hline
\end{tabular}

Notc - Underscored numbers are multivariate results $\mathrm{V}_{\mathrm{A}}=$ not applicable

Home-based group, $N=24$

b The numbers are rather high because of mandatory annual military service for all Israeli men below the age of 54 Under certain circumstances, it may reach 70-80 days per year The average service is about 30 days per year

$* p<05$

sleep $\times$ separation $\left\langle C^{2}=86, d f=2, p=\right.$ 65), which again shows that the communal and home-based groups differ independently with respect to attachment and to separation

To test more specifically the alter native hypothesis that the sleeping arrangement determines the amount of separation exper1ence and that sepuation expenence determines the attachment classification (e $g$, children who are more used to separation may be less anxious in the Strange Situr- tion), we compared two log-linea models The first model contaned 2 two-way interactions sleep $x$ sepalation (modeling the causal link from sleeping arrangement to separation experience) and separation $\times$ classification (modeling the causal link between separation experience and attachment) The fit of this model $\left(G^{2}=608, d f=2, p=\right.$ 048) was compared to the fit of the model in which sleeping arrangement was indirectly as well as directly related to attachment classification This second model contaned the two two-wav interactions of the 
TABLE 2

Sumvary of Stitistics Natrovil Bickchouvd V MRIBLES

\begin{tabular}{|c|c|c|c|c|}
\hline & Communal & Iome Based & $x^{2}$ & $d f$ \\
\hline \multicolumn{5}{|c|}{ Number of chronically ill intants } \\
\hline Chronicallv 11 & 1 & 3 & & \\
\hline No chronic 1 llness & 22 & 22 & $<1$ & 1 \\
\hline \multicolumn{5}{|c|}{ Number of infants after acute illness } \\
\hline Acutely $1 !$ & 18 & 17 & & \\
\hline No acute illness & 5 & $\delta$ & $<1$ & 1 \\
\hline \multicolumn{5}{|c|}{ Piesent maternal job satisfiction } \\
\hline Job is br choice & 16 & 19 & & \\
\hline Job is by assignment & $\vec{i}$ & 6 & $<1$ & 1 \\
\hline \multicolumn{5}{|l|}{ Vaternal bochgound } \\
\hline Kibuutz born & 8 & 9 & & \\
\hline City boin in Israel & ১ & 9 & & \\
\hline Not born in Istael & $T$ & 7 & $<1$ & 2 \\
\hline
\end{tabular}

VOTE - Vone of the $p$ values reached significance

TABLE 3

Stayge Situation Cl issification Disthibutions of IVFatt Mother RELATIOYSHIPS

\begin{tabular}{|c|c|c|c|c|c|c|}
\hline & \multicolumn{2}{|c|}{$\begin{array}{l}\text { COMUUV IL } \\
(N=23)\end{array}$} & \multicolumn{2}{|c|}{$\begin{array}{c}\text { HOWE B BLLD } \\
(N=25)\end{array}$} & \multicolumn{2}{|c|}{$\begin{array}{c}\text { TOF } 12 \\
(V=48)\end{array}$} \\
\hline & $N$ & $\%$ & $N$ & $\%$ & $V$ & $\%$ \\
\hline \multicolumn{7}{|l|}{$A B C^{a}$} \\
\hline Insecule ivoldant & 0 & $(0)$ & 0 & $(0)$ & 0 & $(0)$ \\
\hline Secure & 11 & $(48)$ & 20 & $(80)$ & 31 & (65) \\
\hline Insecule ambivalent ${ }^{b}$ & 12 & $(52)$ & 5 & $(20)$ & 17 & (35) \\
\hline \multicolumn{7}{|l|}{$\mathrm{ABCD}^{\circ}$} \\
\hline Insecure avoidant & 0 & $(0)$ & 0 & $(0)$ & 0 & $(0)$ \\
\hline Secure & $6^{*}$ & (26) & $15^{*}$ & $(60)$ & 21 & $(44)$ \\
\hline Insecure ambivalent ${ }^{b}$ & $7^{*}$ & $(30)$ & $2^{*}$ & (8) & 9 & (19) \\
\hline Disorganized & 10 & $(44)$ & 8 & (32) & 18 & (37) \\
\hline
\end{tabular}

${ }^{2}$ Classification according to the Ainsworth et al (1978) coding svstem including forced classifications (Vin \& Solomon 1990) $x^{2}(1)=542 p=02$

${ }^{b}$ One infant was assessed is insecure albest unclassifible according to the $A B C$ system This result was treated as insecure in the analyses

${ }^{c}$ Classification according to the Man and Solomon (1990) coding rystem $x^{2}(2)=679 p$ $=03$

* Significant adjusted standardized residu 1 s $p<05$

first model supplemented with the sleep $\times$ classification interaction (to model the direct causal link between sleeping arrangement and attachment classification) The fit of the second model $\left(G^{2}=84\right.$, df $=1, p=36$ ) was much better than the fit of the first, ind cating that the alternative hypothesis is implausible Sleeping arrangement has a direct effect of attachment classification independent of separation experiences

\section{Discussion}

The quasi expeumental design em ployed in the present study enabled a com parison of the effects of two different patterns of sleeping arrangements in the kibbutz, communal versus home-based More than half of the infants in communal sleeping arrangements developed insecure attachment relationships with their mothers Only a fifth of home based infants were found to be insecure Other than the frequency and duration of infant-mother separations all background characteristics of the two groups of mothers and infants were essentially the same The quality of darly care in the infants' houses was also revealed to be equvalent across the two groups, demonstr iting the hypothesis that apart from sleep- 


\section{Child Development}

ing urrangements the two groups weie equal Lastly, the groups did not difter on quality of mother-intant interaction in a play session, suggesting that lack of contact at night time for the communal group did not secondarily change the interactions these mothers had with their infants during the day

Although potential threats to internal validitv are inherent in any quasi-experimental design (Cook \& Campbell, 1979), we demonstrated the equivalence of the groups with respect to any important and salient variables Therefore, this study strongly suggests that participating in a communal sleeping arrangement increases the incidence of insecure-ambivalent infantmother attachment This confirms the principal hypothesis 1 he new cohort therefore replicates earlier findings that child-rearing practices in kibbutzim with communal sleeping arrangements may indeed be assocrated with the development of insecure attachment (Sagl et al , 1985)

Every week infants in a communal sleeping arrangement encounter different watchwomen whose task is to look atter their basic needs Clearly, such an arrangement does not allow infants to develop attachment relationships to the watchwomen, who, in turn, cannot serve as a secure base for the infants whenever the infants wake up and requile attention Given that the infants in the communal group cried on average about 10 times per week (Donnell, 1991), these infants indeed experienced distress at night Moreover, it is likely that any intervention by unfamiliar watchwomen in response to distress would elicit stranger anviety in the infant (Bronson, 1986, Spitz, 1965, Tennes \& Lample, 1964), which would further exacerbate the infant's distress From the point of view of attachment theory, the continuous inaccessibility-without adequate replacement-of the mothers as primary attachment figures at night, combined with the mothers being avalable and responsive during the day, may constitute for the infants an inconsistently responsive interaction pattern This caretaking situation is likely to promote insecure-ambivalent relationships between mothers and their infants (Ainsworth et al, 1978), as was the case in more than half of the sample It should be noted that because these infants experience inconsistency between the nature of interactions during the day and the nature of interactions during the night, their experience might be considered as different from the experience of infants with a parent who is continuously avalable physically and yet behaves inconsistentiv toward the infant

The absence of differences between the two groups in the play session, which supports the internal validity of this study's quasi-expermental design, may also seem puzzling in view of attachment theory's clarm that the nature of attachment will be demonstrated in infants daly interactions with their careguers While this deserves further considerition, we propose that although the basic temporal structure of $\mathrm{ma}$ ternal inconsistency might be different for infants in the communal group, the qualitative meaning of the inconsistency is appraised by the intant is not necessurily dif terent in other words, the infant still experiences extremely inconsistent responses from the mother, who is avalable during the day, but absent during the late evening, the entire night, and early morning, when a consoling attachment figure may be needed In a stressful situation like the Strange Situation, the infant shows the ettects of this inconsistent responsiveness, this does not mein however, that the mother s state of mind with regard to attach ment is insecure, and therefore that all her behaviors toward the child must reflect he: own insecurities The infant and his or her mother may be perfectly happy playing with each other under nonstresstul circumstances, because the mother does not necessaily lack the ability to be responsive To measure the disharmony in their relationship, infants and their mothers must be observed in somewhat stressful contexts, in which attachment and sensitivity are really being tested (Smith \& Pederson, 1988) Our play situation did not induce that kind of stress Therefore, we hypothesize that the infants' anomalous experience in the communal sleeping ecology overrides the contribution of the secure personalities of many mothers Intergenerational transmission of attachment is, we suggest, imbedded in, and in extreme cases limited to, the social context in which intant-mother dyads interact (van IJzendoorn, 1992) Obviously, further research should provide more data on the interaction between the role of the social context and the role of the mother's state of mind with respect to attachment

It mav seem surprising that the commu nal sleeping urangement should aler ar tachment secunty so profoundlv, whereas the long separations accompanying lliness and hospitalization do not (van IJzendoorn 


\section{Sagi et al. 1001}

et al, 1992) We suggest, however, that because the nightly separation in the communal sleeping arangement recus as an integral part of the child-care envilonment and is noimative for all the childien in the commumity even sensitive parents may not think it necessay either to compensate tor thu absence durng the night or to commu mate the exceptional nature of the expencnce to the childien (Lewin, 1990) On the other hand, parents of hospitalized intants may consider the nightly separations as unusual and percerve this regume to be stiessful for the child, under these cucumstances, puents often tiy to compensate to the child's hospital experiences, and often will sleep in the childs hospatal room at night when possible Because hospitalization is temporarv, periods of intensive interaction at home may be effective in preventing the development of insecure attachment

Vothers of home based infants left thein for longer and more frequent peirods (e g, for a short holidays without the child) than mothers of communal intants we considcred the number and duration of separations as potential intervening variables, because more separations of a longer duation may be associated with higher rates of attach ment insecunty Speufically, we wele con cenned that mothers of intants participating in a communal sleeping anangement might be inclined to separate from then infants for longer perrods than the mothers with intants in home-based sleeping arangement, because they might percerve such separations as less disruptive of then infants' daly ioutine, and theretore less stresstul for the infants, than mothers of home-based infants In fact, the iesults show the opposite pattein, suggesting that mothers who regulaly care for theu infants at night teel more comfortable in occasionally separating trom them than mothers who do not This is not to imply that infants who sleep at home are more exposed to strangess when then mothers are absent for mole than 24 hous In such cases infants are likely to be under the care of a familar peison (e g, fathes, glandparents, or family triends) in the puvacy of the tamily home (Gerson, 1978) The alternative hypothesis that more frequent and lengthy separations cause infants to feel more at ease in the Strange Situation and therefore display more secure behaviou has not been confiumed, because no relation was found between separation experiences and Strange Situation classifications Out loglinear analyses showed in fact, that the in- teraction effect between sleeping aliangement and Strange Situation classification is mdependent of the interaction between sleeping arrangement and separation experiences

Obviously, the results of the present studs we dependent on the validity of the Strange Situation procedure as a measure for assessing attachment security in the context of a hibbutz In support of this contention, Sagr, Lamb and Gadner (1986) found convergent validity between Stiange Situation behavior and stranger sociability among hibbutz loued intants Oppenherm, Sagr, and Lamb (1988) also discovered that attachment status associated with the metapelet was predictive of later socioemotional development The surtability of the Strange Situation for intants hiving in a communal sleeping anangement was also challenged on giounds that such infants mav not be accustomed to being separated from then parents dunng the tme that they are together This possibility seems to be unlikely in light of previous data (Sagl et al, 1985) showning that Strange Situation classifications were unaffected by timing of assessment Finally, recent meta analvses clemonstrate that, after years of clebate escancling the validity of the Strange Situation in a cross-cultural contest, use of the procedure in varous cultural contevts can be comsidered cross-culturally valid (Sagi, 1990) Sagi, van IJ7cndoom \& Koien-Kane, 1991, van IJzendoom, 1990, van IJzendoom \& Kioonenberg, 1988)

Special attention should be given to the finding that the entric insecure group, in both the communal and home-based settings, consisted of ambivalently attached intants This is congruent with the findings ieported eallex (Sag1 et al, 1985), although the older cohort contaned a tew avordantly attached intants In a comparison of the distributions of $\mathrm{ABC}$ classification data fiom infants in the communal setting, the homebased settung, and Isach mban day-care centers, Donnell (1991) has shown that the various gloups of insecule infants living within an Israeli ecology - whether kibbutz or town-weie moie likely to dovelop insecule ambivalent relationships with the mother than to develop avoidant ielationships Since data all pointing in the same dinection have accumulated, this suggests that some factors unique to Israeli society and yet unexplored mav cause the ovencpresentation of ambivalent attachment

As noted, we have also applicd to ou 


\section{Child Development}

observations the recently developed ABCD attachment classification system, but the disorganized/disoriented category did not change the difference between the communal and the home-based groups In fact, in both groups, the incidence of the disorganized/disoriented attachment relationship seemed to be rather high ( $44 \%$ communal, $32 \%$ home-based), given that these infants come from a normal rather than a clinical population (van IJzendoorn et al, 1992) Because of the overrepresentation of ambivalent attachment relationships within the insecure groups, these infants may be considered as more vulnerable to becoming disorganized/disoriented Furthermore, the wide range of stresstul experiences and hardships that manv Israeli families experıence or have experienced might be consistent with experiences that are theoretically related to disorganized/disoriented behav1ors (Main \& Hess, 1990) At the present, however, it is premature to go beyond just noting this intriguing finding

Although this study focuses on the possible implications for attachment development of participating in an extieme out ofhome environment, that is, in a communal sleeping arrangement, it should be noted that both groups participate in another type of out-of-home care, namely, infant day-care K1 bbutz infants, regardless of whether they are in communal or home-based sleeping arrangements, spend about 9 hours per day, 6 days a week in the infants' house Belsky (1988) described the developmental risks to which childien are exposed when remaining for long periods in a day-care setting during the early years of life Even kibbutz infants in a home-based sleeping arrangement seem to fall into this category, since they are placed in day-care facilities as early as their third or fourth month of life and remain there more than 40 hours per week Since the home-based group setting in fact involves extensive day-care, we may conclude that when good quality care is offered (which is the case in the kibbutz, see Sag1 $\&$ Koren-Karıe, in press), negative effects on attachment security are absent This is not in contradiction with the conclusions of Belsky (1988), who was primarily concerned with nonoptimal day-care facilities (J Belsky, personal communication, Apul 1991)

Whereas dinect experimental manıpulations are impossible if one wishes to study the effects of extiemelv unusurl environments on the development of attachment in humans, the present study was based on an "experiment by nature" (Bronfenbrenner, 1979) We were able to compare kibbutz infants participating in a unique communal sleeping arrangement with their homebased counterparts who were similar in many relevant aspects Our major finding supports the notion that being reared in an environment that significantly deviates from the environment of evolutionary adaptedness (Bowlbv, 1984) indeed has adverse effects on the quality of infant-mother attachment relationships At the same time, it remains intriguing that $26 \%$ of our communally rased infants appeared to be securely attached to their mothers This suggests that the negative effects of a communal sleeping arrangement account for only part of the variance What protective factors were responsible for the development of secure attachments despite the shortcomings of the communal sleeping arrangement remans to be investigated

\section{References}

Ainsworth, $\backslash$ D $S$ Blehar, W $C$, Waters $E$, \& Wall S (19T5) Patterns of attachment Hullsdile, VJ Erlbaum

Aviezer $O$, Sagl, $t$ Donnell F , Harel, Y, Joels, $\mathrm{T}$, \& Tuvia, \ (1989 April) Mother-infant interaction obserued during "lowe hour in hibbutz infants houses and the development of infant-mother attachment Paper presented at the biennial meeting of the Society for Research in Child Development Kansas City, $\mathrm{MO}$

Barnard, $K E$, Hammond, $M$ A, Booth, $C$ L, Bee, H L, Witchell, S K, \& Spieker, S J (1989) Measurement and meaning of parentchild interaction In F Morrison \& $J$ Lord (Eds), Applied psychology (Vol 3, pp 3980) New York tcademic Press

Bates, J E, Freeland, C, \& Lounsbury, V (1979) Measurement of infant difficultness Chuld Development, 50, 794-803

Bayley, $N$ (1969) Bayley Scales of Infant Detelopment New York Psychological Corp

Belsky, J (1988) The "effects" of infant daycare reconsidered Early Childhood Research Quarterly, 3, 235-272

Belsky, J, \& Braungart, J M (1991) Are insecureavoidant infants with extensive davcare experiences less stressed by and more independent in the Strange Situation? Child Development, 62, 567-571

Belsky, J, \& Walker, A (1980) Infant-Toddler Center Spot Observation System Unpublished manuscript Pennsvlvaniz State Universitv, Unusersity Puh

Bowlby, J (1973) ditachment and loss Vol 2 Separation London Pengun 
Bowlby, J (1984) Attachment and loss Vol 1. Attachment (2d ed) London Pelican

Buslin, R W (1980) Tianslation and content analysis of oral and wutten matenal in $\mathrm{H} \mathrm{C}$ Truandis \& R W Brishin (Eds), Handbook of cross-cultural psychology/social psychology (Vol 2, pp 389-444) Boston Allvn \& Bacon

Bonfenbrenner, U (1979) The ecology of human clevelopment Experments by nature and design Cambudge, MA Harvard Unueisity Press

Bionson, G W (1968) The development of fear in man and other anmals Chald Development, 39, 409-432

Cook, T D, \& Campbell, D T (1979) Quasterperimentation Design and analysis issues of field settings Chicago Rand Mc. Nally

Donnell, F (1991) The impact of famuly-based versus communal sleeping arrangements on the attachment relationships of hibbutz infants Unpublished master's thesis, School of Soclal Work, University of Haifa, Israel

Cerson, $M$ (1978) Famlly, women, and socialization in the kibbutz Lexington, MA Lexington Books/Heath

Hock, E (1984) The tannsition to daycale Effects of maternal separation anxiety on infant ad Justment In R Anshe (Ed), Quality varation in daycare lmplications for child development (pp 183-205) New York Praeger

Hock, E, \& Clinger, J B (1981) Infant coping behaviors Then assessment and therr relation to maternal attributes Journal of Genetic Psychology, 138, 231-243

Hock, E, DeMeis, D K, \& McBride, S L (1988) Waternal separation anriety Its role in the balance of employment and motherhood in mothers of infants In A Gottfried \& A Gottfried (Eds), Maternal employment and chuldren's development Longitudinal research (pp 191-227) New York Plenum

Hock, E, McBride, S L , \& Gnezda, M T (1989) Maternal separation anxiety Mother-1nfant separation from the maternal perspective Child Development, 60, 793-802

Lamb, M E, Hwang, C, Bookstem, F L, Broberg, A, Hult, G , \& Frodı, M (1988) Determinants of competence in Swedish pieschoolers Developmental Psychology, 24, 58-70

Lavi, Z (1982, April) Correlates of sleepming arrungements of infants in kibbutzim Paper presented at the International Conference of Infant Studies, New York

Lewin, G (1990) Notherhood in the kibbutz In Z Lavi (Ed), Kibbutz members study kibbutz chuldren (pp 34-39) New York Greenwood

Man, M, \& Hess, E (1990) The parents of insecure-disorganized/disoriented infants Observations and speculations In $M T$ Gicenbeig.
D Cicchett, \& E $\backslash$ Cummings (Eds), Attachment in the preschool years Theory rescarch and intercention (pp 161-184) Chicago University of Chicago Press

Man, in \& Solomon J (1090) Proceducs tor identifiving infunts as disorganized/disonented durng the linsworth Strange Situation in $M T$ Treenberg, D Cicchetti, \& E II Cummings (Eds), Attuchment in the preschool years Theory researeh and inter cention (pp 121-160) Chuago Unueisity of Chacago Press

Oppenhem, D, Sagr \& \& Lamb U L (1988) Intant-aduit attachunents and then ielation to socioemotional development lou va.us hater Developmental Psychology 24, 427-433

Sagk, $d(16)(0)$ Attachment theors and lesearh from a cross-cultural perspective IItman De velopment $33,10-22$

Sayl, A, \& Koren-Kune iv (in piess) Dav-case centers in Israel troverview In $M$ Cochin (Ed), International handbooh of day-care policus and programs New Yoik Gicenwood

Sag1, A, Lamb, W E, \& Cardner, W (1986) Relationships between Stiange Situition behavior and stranger socubiblity among infunts on lsraelı kibbutzim Infant Behavior and Development, 9, 271-282

Sagi, A, Lamb, V E, Lewkowicz, K, Shoham, R, Dvir, R, \& Estes, E (1985) Secunty of intant-mother, -Father, and-metapelet attachments among kibbutz-1eared Israeli childien In I Bictherton \& E Waters (Eds), Giowing points in attachment theory and research (pp 257-275) Monographs of the Soctety for Research in Chuld Deuelopment, 50(1-2, Serial No 209)

Sugi, A, van IJzendoorn, M H, \& Koren-Karie, $N$ (1991) Primary appiasal of the Strange Situation A cross-cultural analysis of the preseparation episodes Developmental Psychology, 27, 587-596

Smith, P B , \& Pederson, D R (1988) Mateinal sensitivity and patteins of mlant-mother at tachment Child Deuclopment, 59, 1097 1101

Spitz, R A (1965) The first year of life A psychoanalytic study of deviant object relations New-York International Unversities I'ress

Tennes, K 11, \& Lample, E E (1964) Stranget and separation anvety in infancy journal of Nervous and Mental Disease, 139, $247-$ 254

Tiger, L \& Shepher, J (1975) Women in the kabbutz New York Hancout Brace Jovanovich van IJzendoom, $V$ H (1990) Developments in cross cultural reseurch on attachment Some methodological notes Human Developinent, $33,23-30$ 


\section{Child Development}

van IJzendoorn, $M$ H (1992) Intergenerational transmission of parenting A review of studies in nonclinsal populations Developmental Revie:v, 12, 76-99

van IJzendoorn, if $\mathrm{H}$, Goldberg, $S$, Kioonenberg, P M, \& Frenkel, O J (1992) The relauve effects of maternal and child problems on the quality of attachment A meta-analysis of attachment in clinical samples Child Development, $63,840-858$

van IJzendoorn, $\forall H$, \& Kroonenberg, $P \quad V$ (1988) Cross-cultural patterns of attachment A meta-analysis of the Strange Situation Child Development, 59, 147-156 
scaucntly we expected to find an unusually high late of insecure attachments among such infants Employing the Strange Situation piocedure (Answorth, Blehar, Waters, \& Vall, 1978), we found that infants rased in this ecology were indeed classified as inscume-ambivalent to a greatel estent that in most other cross-cultural samples (Sagr, 1990, van IJzendoon \& Kıonenberg, 1988)

In the ecology of a traditional kibbutz with communal sleeping ariangements, inhats are moved into the intants' house at 6 weehs of age There infants are cared for $1 \mathrm{n}$ small groups br protessional caretakers while theil mothers visit regularly to teed and bathe them throughout the first year Dunng the night, two watchwomen are lesponsible tor all the childien under the age of 12 years on the kibbutz. The watchwomen ue egular members of the krbbutz who contribute 1 week about every 6 months on a lotation bass, and they are responsible for monitoring via intercom a number of the children's houses fiom a central location, usually the infants' houses Thus, at nught the adults avalable to the infants (a total of about 50 women) are often unfamilias and unable to iespond promptly of necessity, then, infants are never able to establish a duable bond with the adults avaluble to them at night

Two major chalacteristics of this ecology may account for the overrepresentation of insecure-ambivalent attachment in kibbutz infants $F_{1 u s t}$ as alieady mentroned, there is likely to be substantial deldy as well as inconsistent responsiveness to distress at night, when infants aie monatored by various unlamilat watchwomen Second, infants are continuously being exposed to inconsistent mateinal caretaking That is, while mothers are quite avalable during the day, they become inaccessible at night The mothers, therefore, cannot be considered rejecting of the attachment behaviois of then infantswhich would-lead to insecure-avoidant attachment-but then infants necessanly experience inconsistent iesponsiveness to thei attachment signals, which has been descrubed as a piecursol to insecuie-ambivalent attachment (Ainsworth et al, 1978, Bowlby, 1973, 1984)

The present study was designed not only to replicate the initial exploratory study but also to examine our previous explanations We have suggested that the critical factor in the oveliepresentation of ambivalont attachments in the exlier study is the communal slecpung arangement and its concomitants The ealler study included only infants residing in kibbutzim with communal sleeping arrangements, but without an adequate companson group, ou explanations regarding the antecedents of the ove. repiesentation of ambivalent attachments remaned speculative In the present study, we include a group of kibbutz intants a ased with hone-based sleeping anangements In both communal and home-based settings, infants spend about 9 hours each day ( 6 working days) in the care of metaplot who are the infants primarv caregivers (Hebiew s metapelet, pl metaplot) All infants spent the hours of $4-\delta \mathrm{P} \vee$ at home with theu parents Intants aesiding in hibbutzm with home-based sleepme arangements iemanned wath then familes for the mint, whereas infants lesiding in kibbutzim with communal sleeping ariangements were retumed to the intants houses at about $8 \mathrm{P} . \mathrm{M}$ by then parents to be settled for the night and remaned under the care of watchwomen until moining

Including a companson group from home-based kibbutzim allowed us to tocus on the differentral effects of two kinds of sleeping wangements while also controlling tor potential intervening faclons Our pincipal hypothesis is that more kibbut $\angle$ intants raised within a communal setting will be insecurely attached to then mothers than infants iased within a home-based setting To minmize the possibility of alternative explanations, it was ciucial to test the hypothesis that the home-based and communal groups of mothers and infants were similar in regard to a number of background and potentrally intervening variables Indeed, we hypothesized that, apart from infant sleeping allangements, all mothers and mfants were diawn trom the same population It was further hypothesized that the quality of care in the infants' houses duing the daytime was the same across the two groups of infants Thus, if difterences were tound between the attachment distilutions of two groups, then this difference mav be explaned as an outcome of the difference between the homebased and communal sleeping arrangements

\section{Method}

Procedure

The aim of the research design presented here was to compare two groups of infants who differed onlv in teims of then sleepung arangements home-based as op- 